believe that a transformational process is presently underway and we are not only analysts of it, but advocates and practitioners as well. We see the contemporary American movements in civil rights, feminism and ecofeminism, environmental protection, nonviolence and conflict resolution, participatory democracy, Green and New Age politics as being part of this transformational process.

We seek panels and papers that address the promise and performance of these (and other) components of this transformational process and period. Papers may be rigorous and systematic or theoretical and anecdotal. We also sponsor a series of support groups in the evenings during the APSA where we discuss our personal experiences, problems and challenges as those who practice this kind of politics as professors of political science-in the workplace, in politics and in our personal lives. Those who have experience as facilitators or mediators are encouraged to write us about participating as such in the support groups.

Caucus for a New Political Science.* Joe Kling, Department of Government, St. Lawrence University, Canton, NY 13617; (315) 379-5214 or 379-5279.

The purpose of this section is to bring together those individuals who identify with a critical and activist approach to the study of political science. We seek papers across the broadest possible spectrum of the discipline. But we expect these papers will share the conviction that the study of politics is never value-free, and that political scientists, whatever their field or focus, have an active responsibility to connect their understanding to the search for human betterment and social justice.

While we have not decided upon a specific set of themes for the 1991 meeting, we are generally interested in the following areas:

(1) Currents in critical political theory, including discussions of NeoMarxism, Critical Theory, The Politics of Culture, Feminist Theory, and The Idea of a New Political Science.

(2) Contending Perspectives on Democracy and Development, including discussions of Latin America, Asia, Middle East, Africa, Women in the Third World.

(3) Racial and Ethnic Politics.

(4) The Politics of Gender.

(5) International Political Economy, Political Responses to the Globalization of the Economy, Intervention in Third World Politics.

(6) Urban Political Economy, Community Politics.

(7) Social Movements in Western Europe and America, Political Transformation in Communist Systems, Agendas for the Left.

If there are other topics or themes in which you would be interested, we invite your suggestions and proposals.

*Organized sections.

\section{APSA Research Grantees Announced}

The APSA Research Support Committee announced the $1991 \mathrm{Re}$ search Grantees on May 1. The Council established the research grant program in 1984, and authorized $\$ 15,000$ to be distributed annually. To be eligible for a grant the applicants must be APSA members and must either be a faculty member at a non-Ph.D. granting college or university or be a political scientist not affiliated with an academic institution. Funds are used for research that addresses a significant problem in political science.

The Selection Committee, composed of Gary Jacobson, University of California, San Diego, chair; Donna Bahry, University of California, Davis; G. Chris Garcia, University of New Mexico; Roy F. Grow, Carleton College; and Timothy Tilton, Indiana University, reviewed 50 applicants and made 10 awards.

Donald L. Davison, Rollins College, "Ambition, Reform, and Retirement: A Survey of Retirees from the U.S. House of Representatives, 19571988."

Carol J. Hager, Bryn Mawr College, "Environmentalism and Democracy in the Two Germanies."

Michael S. Hamilton, University of
Southern Maine, "Politics and Decision Making in State Regulation of Electricity Development Proposals."

Cheryl M. Miller, University of Maryland, Baltimore County, "Choice and Strategy in Issue Selection by State Legislative Black Caucuses in the South."

Samory Rashid, Indiana State University, "The Political Environment and Foreign Direct Investment Decisions."

Wilma Rule, University of Nevada at Reno, "Women and Political Recruitment in Four Democratic Nations."

Peter Rutland, Wesleyan University, "Labor Movements in the Transition to a Market Economy: The Czech Case."

Catherine Scott, Agnes Scott College, "Women and Development in Regional Organizations: SADCC in the 1990s."

W. Rand Smith, Lake Forest College, "States and Economic Crisis: The Politics of Industrial Restructuring in Socialist France and Spain."

Jerry D. Stubben, Iowa State University, "Nations within Nations: Tribal Government Survey."

\section{Ralph Bunche Summer Institute}

Twenty-five rising juniors were selected to participate in the sixth annual Ralph Bunche APSA Summer Institute in Political Science for Black Students, held June 10-July 20 in Atlanta, Georgia.

The Institute was conducted by a consortium consisting of Spelman College, Morehouse College, Georgia State University, Clark Atlanta University and Emory University. Lois Moreland of Spelman was director of the 1991 institute. Naomi Lynn of Georgia State, Eleanor Main and Micheal Giles of Emory University, Tobe Johnson of Morehouse, and William Boone of Clark Atlanta were coordinators of their respective campuses.

The students selected as institute participants came from diverse universities and colleges from 14 dif- 